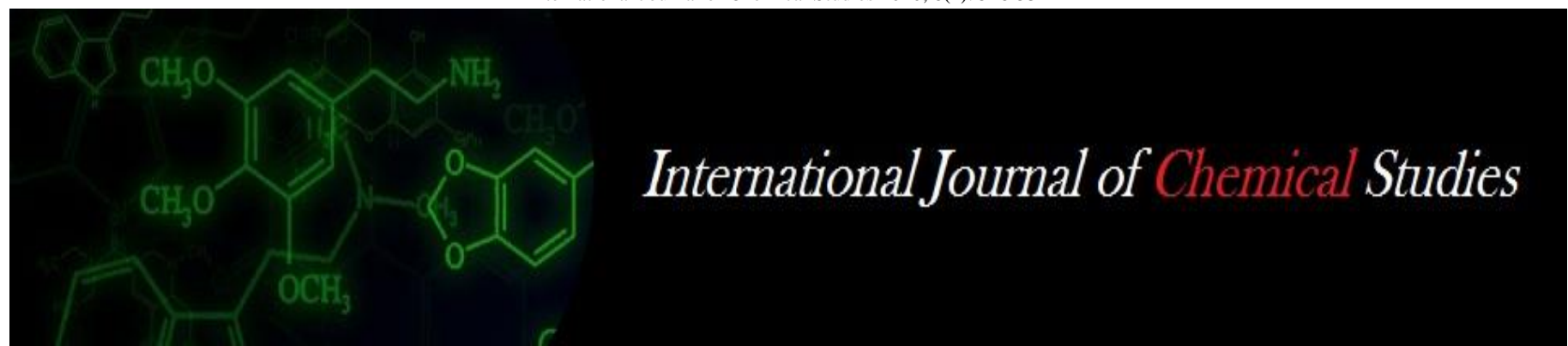

P-ISSN: 2349-8528

E-ISSN: 2321-4902

www.chemijournal.com

IJCS 2020; 8(1): 528-531

(C) 2020 IJCS

Received: 16-01-2019

Accepted: 22-02-2019

\section{Deeksha Choudhary}

Department of Soil Science and

Agriculture Chemistry, College of

Agriculture CSK Himachal

Pradesh Agricultural University,

Palampur Himachal Pradesh,

India

\section{SP Dixit}

Department of Soil Science and Agriculture Chemistry, College of Agriculture CSK Himachal

Pradesh Agricultural University, Palampur Himachal Pradesh, India

\section{Nagender P Butail}

Department of Soil Science and Agriculture Chemistry, College of Agriculture CSK Himachal Pradesh Agricultural University, Palampur Himachal Pradesh, India
Corresponding Author: Deeksha Choudhary

Department of Soil Science and Agriculture Chemistry, College of Agriculture CSK Himachal Pradesh Agricultural University, Palampur Himachal Pradesh, India

\section{Response of soil test crop response (STCR) approach on available nitrogen, phosphorus and potassium status after Wheat (Triticum aestivum L.) harvest in an acid Alfisol}

\section{Deeksha Choudhary, SP Dixit and Nagender P Butail}

DOI: https://doi.org/10.22271/chemi.2020.v8.i2h.8821

\begin{abstract}
The field experiment was carried out on wheat during rabi, 2017-18 to study the prescription based fertilizer application on soil properties in a long term experiment of Department of Soil Science CSK HPKV, Palampur. The experiment was laid out by Randomized block design (RBD) consisting of eight treatments which are replicated thrice. The application of fertilizers based on soil test crop response (STCR) along with application of FYM @ 5 $\mathrm{tha}^{-1}$ recorded significantly higher available $\mathrm{N}, \mathrm{P}$ and $\mathrm{K}$. Further the physical properties such as bulk density, particle density, porosity and water holding capacity were observed when compared to the other treatment combination carried out during the experiment viz., general recommended dose (GRD) of NPK, control, soil test based. Overall, we concluded that the input of STCR approach had positive effects on soil properties.
\end{abstract}

Keywords: Wheat, Soil test crop response (STCR), Randomized block design (RBD), general recommended dose (GRD)

\section{Introduction}

Wheat is an important cereal crop of the world cultivated over an area of 30.60 million hectares with a production of 98.38 million tonnes in the country (Anonymous 2017) ${ }^{[1]}$. Among the various factors affecting the growth, nutrient management practices plays a vital role in sustaining the productivity of crops. Presently the chemical fertilizers are used as a major source of nutrients which increases the energy cost, economic pressure and increases environmental degradation. Due to escalating cost coupled with increasing demand of chemical fertilizers and deteriorating soil health necessitates the safe and adequate method of fertilizer application. The effective fertilizer recommendation should consider crop needs and nutrient already available in the soil (Tegegnework et al. 2015) ${ }^{[6]}$. Among the different methods of fertilizer recommendation viz., general recommended dose (GRD), soil test based recommendation, etc., soil test crop response (STCR) is unique in indicating both soil test based fertilizer dose and the level of yield can be achieved with good agronomic practices (Singh et al. 2005) ${ }^{[4]}$. Farm yard manure along with target yield based fertilizer application not only revamp soil health but also improves soil properties. As wheat is an important cereal crop after rice therefore, this study was conducted to investigate the effect of fertilizer prescriptions by different approaches on soil properties.

\section{Material and Methods}

The present study was carried out in an ongoing long term fertilizer experiment in rabi, 201718 at Chaudhary Sarwan Kumar Himachal Pradesh Krishi Vishvavidyalaya, Palampur, India. Geographically the experimental field is situated at $32^{\circ} 6^{\prime} \mathrm{N}$ latitude and $76^{0} 3^{\prime}$ E longitude at an elevation of $1290 \mathrm{~m}$ above mean sea level. The soil of the experimental site belongs to silty clay loam texture and soil order Alfisol. Climate of palampur region with the average maximum and minimum temperature is $36^{\circ} \mathrm{C}$ and $3.1^{\circ} \mathrm{C}$ respectively.

The experiment was laid out in RBD design with eight treatments wich were replicated three times with plot size of $15 \mathrm{~m}^{2}$. Sowing of the crop was done in November 2017 with a seed rate of $100 \mathrm{~kg} \mathrm{ha}^{-1}$ with row to row spacing of $22 \mathrm{~cm}$. Placement of solid fertilizers in the soil was 
done as basal dose in which half dose of nitrogen and full dose of phosphorus and potassium was applied at the time of sowing. Remaining half nitrogen was applied in two equal splits at tillering and flowering stages. The soil analysis results before sowing revealed that it was low in available nitrogen, medium in available phosphorus and potassium. The experiment has Eight treatments, Viz.,

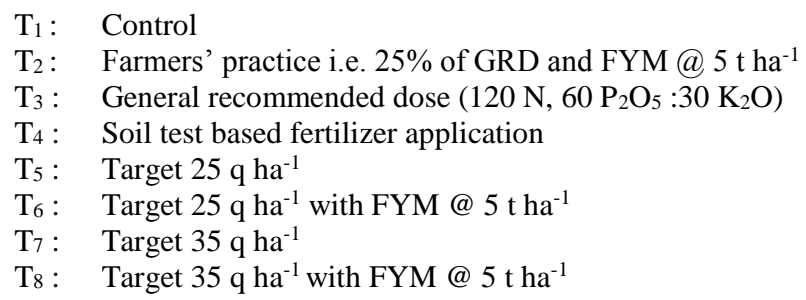

The targeted yield equations developed for wheat crop were used for the calculation of fertilizer $\mathrm{N}, \mathrm{P}_{2} \mathrm{O}_{5}$ and $\mathrm{K}_{2} \mathrm{O}$ :
$\mathrm{FN}=5.27 \mathrm{~T}-0.25 \mathrm{SN}-1.06$

$\mathrm{FP}_{2} \mathrm{O}_{5}=4.13 \mathrm{~T}-0.38 \mathrm{SN}-0.98 \mathrm{OP}$

$\mathrm{FK}_{2} \mathrm{O}=2.87 \mathrm{~T}-0.15 \mathrm{SN}-0.55 \mathrm{OK}$

Using the above adjustment equation the quantity of nutrient reqyuirements for achieving $25 \mathrm{q} \mathrm{ha}^{-1}$ and $35 \mathrm{q} \mathrm{ha}^{-1}$ were worked out. The fertilizer $\mathrm{N}, \mathrm{P}_{2} \mathrm{O}_{5}, \mathrm{~K}_{2} \mathrm{O}$ applied in $\mathrm{T}_{5}$ and $\mathrm{T} 7$ were 63:84:30 $\mathrm{kg} \mathrm{ha}^{-1}$ and 45:97:37 $\mathrm{kg} \mathrm{ha}^{-1}$, respectively.

\section{Results and Discussion \\ Available nitrogen}

Data pertaining to soil avalaible nitrogen (Fig. 1) ranged from $148 \mathrm{~kg} \mathrm{ha}^{-1}$ in control to $305 \mathrm{~kg}$ ha-1 in treatment target yield $35 \mathrm{q} \mathrm{ha}^{-1} \cdot \mathrm{K}_{2} \mathrm{O}$. The available nitrogen under target yield $25 \mathrm{q}$ ha $^{-1}$ were improved by 6.0 and 3.7 per cent over general recommended dose and soil test based fertilizer application, respectively. This might be due to the reason that prescription based fertilizer application provides balanced application of fertilizer nutrients (Singh et al. 2016) ${ }^{[5]}$.

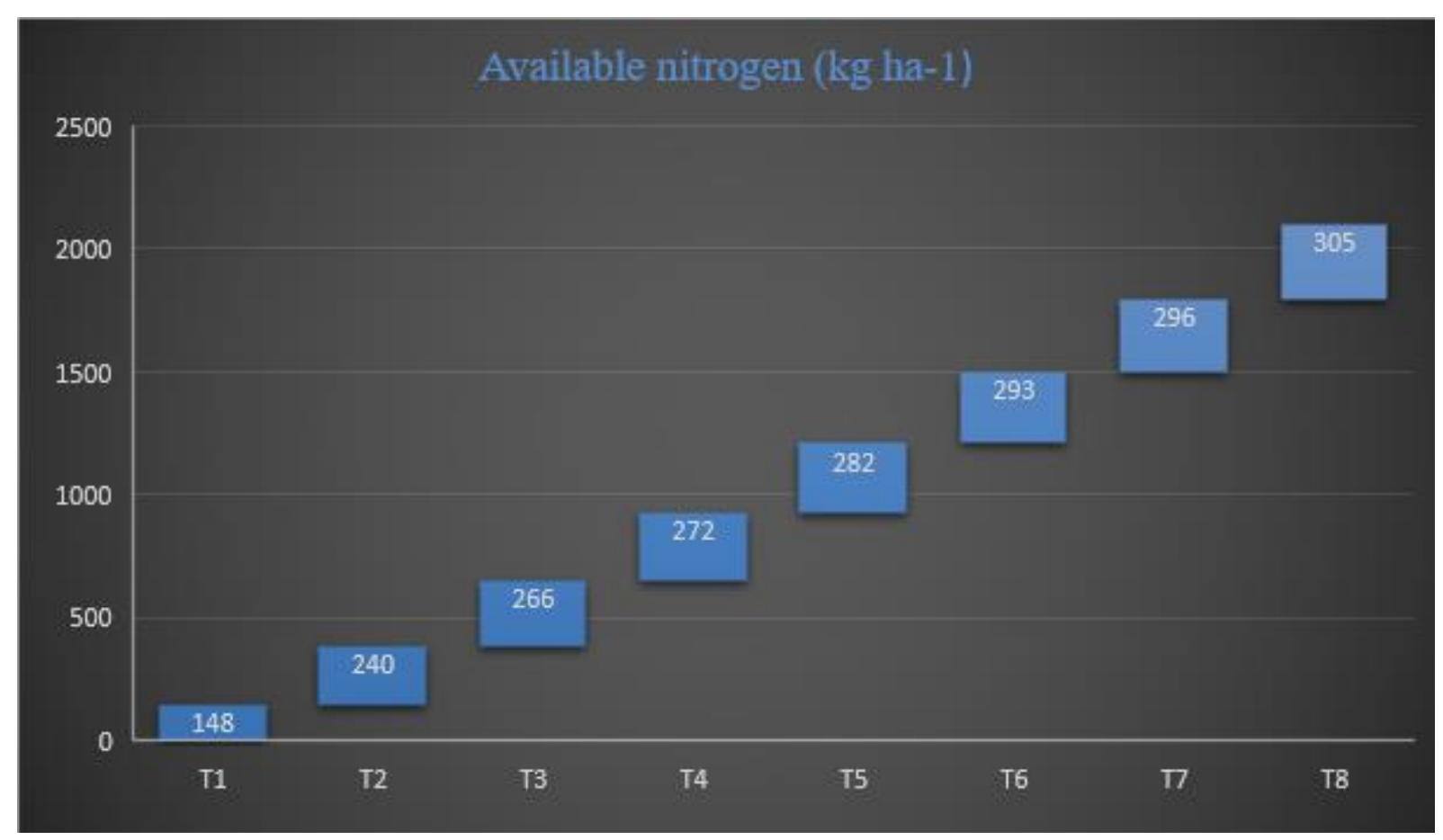

Fig. 1. Effect of prescription based fertilizer application on available nitrogen

The higher increase in available $\mathrm{N}$ incase of target yield $35 \mathrm{q}$ ha-1 with IPNS was due to the addition of FYM and also found to be statistically at par with same treatment but without FYM.

\section{Available phosphorus}

Different nutrient management practices had significant effect on soil available phosphorus (Fig. 2). Treatment $\mathrm{T}_{8}$ (target yield $35 \mathrm{q} \mathrm{ha}^{-1}$ ) was significantly superior over all other treatments with a value of $70 \mathrm{~kg} \mathrm{ha}^{-1}$. The farmers' practice improved it's content by 52.2 per cent over control. The treatment target yield $25 \mathrm{q}$ ha-1 without Fym recorded a significant increase in it's status by 2.1 and 14.3 per cent over general recommended dose and soil test based, respectively. This might be due to the specific balanced amounts of $P$ fertilizer were prescribed based on the estimates of indigenous supply. Build up of available P with the application of NPK fertilizer alone or in 


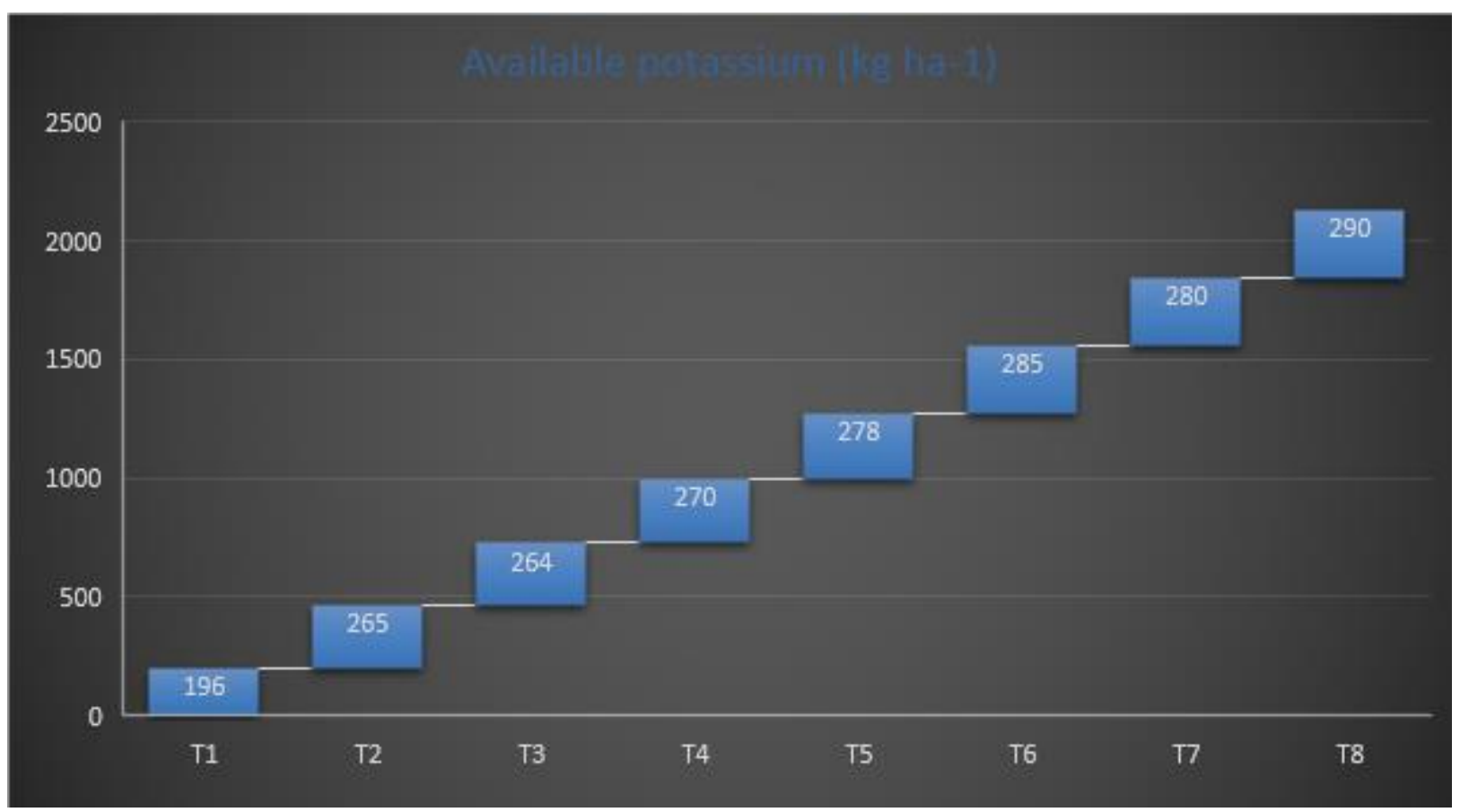

Fig. 2. Effect of prescription based fertilizer application on available phosphorus

Conjugation with FYM might be due to the release of organic acids during decomposition which in turn helped in releasing phosphorus through solubilizing action of native phosphorus in the soil (Sharma et al. 2016).

\section{Available potassium}

The results in figure 3 indicated that available potassium ranged from $196 \mathrm{~kg} \mathrm{ha}^{-1}$ in control to $290 \mathrm{~kg} \mathrm{ha}^{-1}$ in treatment comprising of target yield $35 \mathrm{q} \mathrm{ha}^{-1}$ with FYM. The farmers' practice and general recommended dose increased it's content by 35.2 and 34.7 per cent over control. The depletion of available potassium in control might be due to continuous cropping, mining of soil native pool and also no addition of external sources.

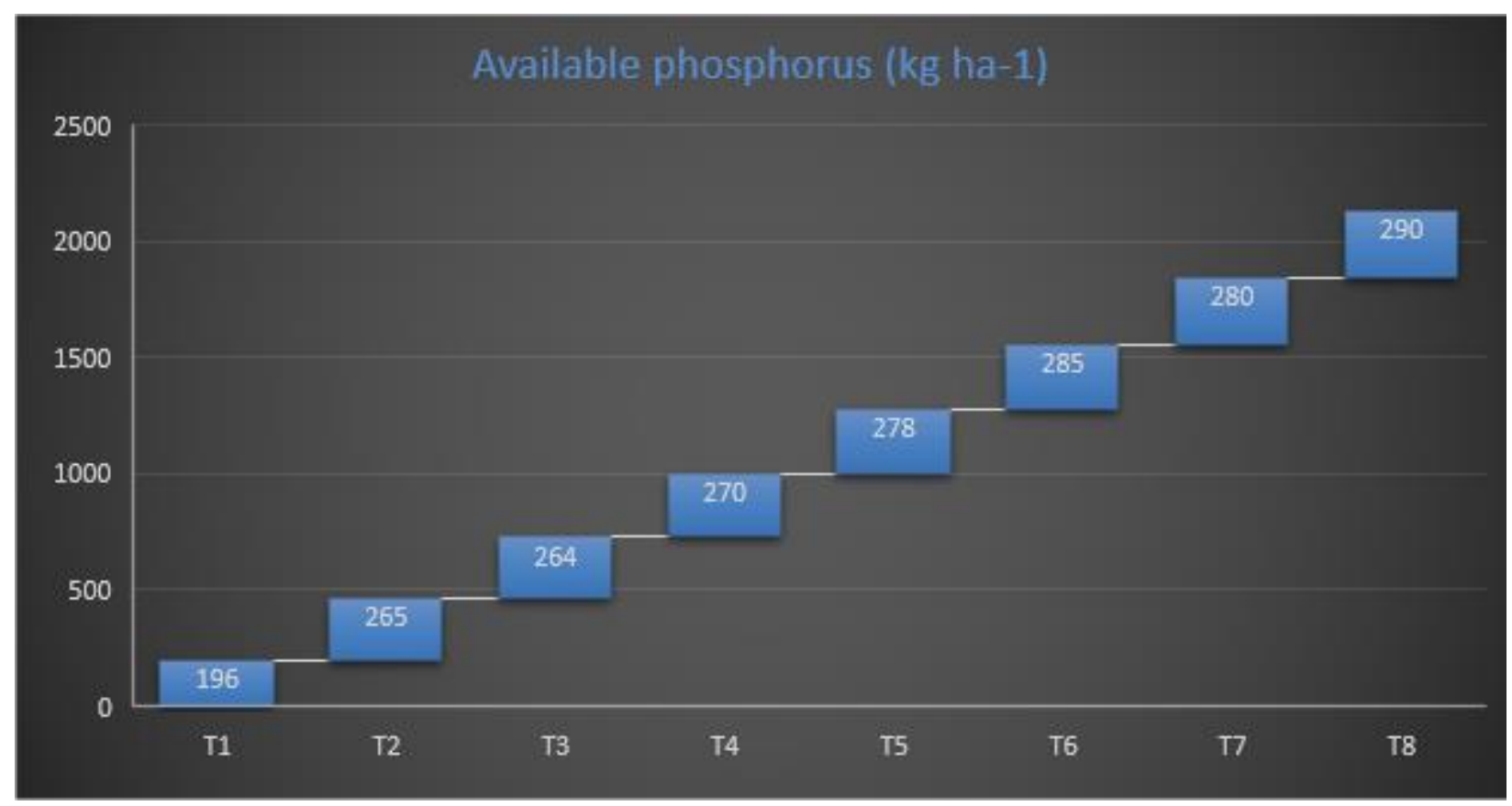

Fig 3: Effect of prescription based fertilizer application on available potassium

The treatment target yield $25 \mathrm{q} \mathrm{ha}^{-1}$ without FYM was found to be statistically at par with soil test based, target yield $25 \mathrm{q}$ ha $^{-1}$ with FYM and target yield $35 \mathrm{q} \mathrm{ha}^{-1}$ without FYM. However, the highest content in target yield treatments without FYM owing to the balanced application based on STCR approach which takes into account the crop removal and inherent capacity of soil and as such sustains the soil fertility status (Sahu et al. 2017) ${ }^{[2]}$.

\section{Conclusion}

The results of this experiment revealed that prescription based fertilizer application for desired yield target significantly improved the available N, P and K status as compared to other approaches of fertilizer application. This positive effect $t$ may be due to the judicious use of fertilizers and integrated supply of nutrients. The specific yield equation will not only ensure 
sustainable crop production but will also steer the farmers towards economic use of costly fertilizer inputs.

\section{Acknowledgement}

A special thanks to CSK Himachal Pradesh Krishi Vishvavidyalaya Palampur (HP) for providing me the special facilities to conduct the investigation.

\section{References}

1. Anonymous. Agriculture Research Data book, Ministry of Agriculture, Government of India, 2017.

2. Sahu V, Srivastava LK, Mishra VN. Soil test based fertilizer prescriptions through integrated nutrient management using targetyed yield approach for SRI rice (Var. Swarna) in Vertisols of Chattisgarh, India. International Journal of Current Microbiology and Applied Sciences. 2017; 6:2824-2835.

3. Sharma VK, Pandey RN, Kumar S, Chobhe KA, Chandra S. Soil test crop response based fertilizer recommendations under integrated nutrient management for higher productivity of peral millet (Pennisetum glaucum) and wheat (Triticum aestivum) under long term experiment. Indian journal of Agricultural Sciences. 2016; 86:1076-1081.

4. Singh KN, Raju NS, Subba AR, Abhishek R, Sanjay S, Samanta RK, et al. Prescribing optimum dos of nutrients for targeted yield through soil fertility map in Andhra Pradesh (AP). Journal of Indian Society of Agricultural Statistics. et al. 2005; 59(2):131-140.

5. Singh YV, Dey P, Meena R, Varma SK. Effect of soil test based application on yield and economics of chickpea in inceptisol. Annals of Plant and Soil Research. 2016; 18:409-412.

6. Tegegnework GW, Shanwad UK, Desai BK, Koppalakar BG, Shankergoud I. Response of soil test crop response (STCR) as an optimizing plant nutrient supply on yield and quality of sunflower (Helianthus annuus L.). African Journal of Agricultural Research. 2015; 10(28):26802686. 